\section{Hepatitis B and C in household and health services solid waste workers}

\author{
Hepatite B e C em profissionais que coletam \\ resíduos de serviço de saúde e domiciliares
}

\section{Hepatitis B y C en los trabajadores responsables de la recolección de residuos sólidos domiciliarios y de servicios de salud}

\author{
${ }^{1}$ Centro de Pesquisas e \\ Desenvolvimento, Fundação \\ Ezequiel Dias, Belo \\ Horizonte, Brasil. \\ 2 Faculdade de Medicina \\ Universidade Federal de \\ Minas Gerais, Belo Horizonte, \\ Brasil. \\ 3 London School of Hygiene \\ and Tropical Medicine, \\ London, U.K. \\ 4 Escola de Engenharia, \\ Universidade Federal de \\ Minas Gerais, Belo Horizonte, \\ Brasil. \\ Correspondence \\ M. P. G. Mol \\ Centro de Pesquisas e \\ Desenvolvimento, Fundação \\ Ezequiel Dias. \\ Rua Conde Pereira Carneiro \\ 80, Belo Horizonte, $M G$ \\ 30510-010, Brasil. \\ marcos_mol@yahoo.com.br
}

\begin{abstract}
Human contact with solid waste poses biological, chemical, and physical health risks for workers involved in waste collection, transportation, and storage. The potential risk to human health resulting from contact with health services waste or household waste still sparks considerable controversy. The aim of this study was to identify the context of scientific discussions on risk/infection from the hepatitis $B$ and $C$ viruses in workers that collect solid waste from health services or households. The search covered publications up to 2013 in Brazilian and international databases, and 11 articles were selected through a literature review. Of these, six conclude that there is an increased risk of infection in workers that collect household waste when compared to those unexposed to waste, three point to greater risk for workers that collect health services waste as compared to those that collect ordinary waste, and the other two found no difference between exposed and unexposed individuals.
\end{abstract}

Solid Waste; Hepatitis B; Hepatitis C;

Urban Health

\author{
Marcos Paulo Gomes Mol 1 \\ Dirceu Bartolomeu Greco 2 \\ Sandy Cairncross ${ }^{3}$ \\ Leo Heller ${ }^{4}$
}

\section{Resumo}

O contato humano com os resíduos implica riscos biológicos, químicos e físicos à saúde dos trabalhadores envolvidos com a coleta, o transporte e o armazenamento. O potencial de risco para a saúde humana decorrente do contato com os resíduos de saúde ou domiciliares ainda gera muita polêmica. Sendo assim, a proposta deste trabalho foi de identificar o contexto das discussões científicas sobre risco/infecção pelos vírus das hepatites $B e$ $C$ em trabalhadores que coletam resíduos de serviço de saúde ou domiciliares. As buscas abrangeram publicações até 2013 em bancos de dados nacionais e internacionais, sendo selecionados 11 artigos através de uma revisão da literatura, dos quais seis concluem que há maior risco de infecção nos trabalhadores que coletam resíduos domiciliares se comparados com os não expostos aos resíduos, três estudos apontam haver maiores riscos entre os profissionais que coletam os resíduos de saúde se comparados com aqueles que coletam os resíduos comuns, e outros dois concluem não haver diferenças entre expostos e não expostos.

Resíduos Sólidos; Hepatite B; Hepatite C; Saúde Urbana 


\section{Introduction}

The management of urban solid waste in urban centers is growing in complexity and receiving increasing attention from researchers because of the potential impact on the environment and on human health if not well managed 1,2,3,4. Workers involved in management of these wastes are exposed to biological, chemical and physical risks to their health $2,5,6,7,8$.

Of the types of solid waste, health care waste are particularly likely to contain biological and chemical agents 9 . Only a fraction of urban solid waste are potential sources of disease for those who have inadequate contact with them. A particular risk is that of injury or infection from sharps 10,11 .

The risk to human health from health care waste, compared to that from urban solid waste in general, is a subject of debate among researchers and managers. Some have claimed that the handling of health care waste involves additional risks to health, beyond those arising from domestic waste $6,9,12,13,14$. Others, however have denied that there is any difference between the two $15,16,17,18$.

Two reviews of the literature were found, one of which 12 focused on studies of hepatitis A and $B$ in workers who handled waste, but only one of the papers identified involved an epidemiological study 19; another review 20 selected five crosssectional studies, of which four correspond with papers in Table 1 19,21,22,23.

The aim of this review was to identify the context of scientific discussion on hepatitis $\mathrm{B}$ and C infection in workers who collect solid waste, whether domestic or from health care facilities, in order to assess the balance of evidence on this subject. The subject has relevant implications for urban health, considering its links with waste production by an increasingly urbanized population, environmental determinants, and the social vulnerability of the population occupationally involved in waste management.

\section{Methodology}

The search was carried out between January and December 2013, accessing the world's major publication databases, including: Web of Science, Web of Knowledge Cross Search, SciELO, and MEDLINE/PubMed.

The following search terms were used: hepatitis, prevalence of hepatitis, health care waste, medical waste, biomedical waste, solid waste, waste, waste workers, municipal solid waste workers, medical waste handlers and health care workers. All studies in which the health outcome was infection with hepatitis $\mathrm{B}$ or $\mathrm{C}$ virus in workers who collect domestic or health care waste were reviewed. No criterion was set regarding the size or gender of the study population.

\section{Results}

Figure 1 shows the process of screening and evaluation. Eleven papers met the requirements for inclusion in this review. Table 1 shows the general characteristics of the included studies.

Six of the studies concluded that workers collecting urban solid waste are exposed to greater risk when compared with those who have no exposure $19,21,22,23,24,25$, although one study found no such additional risk 5 . With regard to health care waste, three studies indicate higher risk among those collecting than those working with urban solid waste $26,27,28$, and a fourth study found none 29 .

Four of the papers included consider workers who collect hospital waste $26,27,28,29$, comparing with workers dealing with ordinary refuse. The study by Ferreira et al. 29 involved hospital and municipal waste collection workers, compared with others who covered residential areas.

\section{Discussion}

All papers used cross-sectional study designs, limiting the possibility of assessing a cause and effect relationship by making it difficult to identify the moment at which infection occurred.

Some studies determined that immunization against HBV and being under treatment for the disease should be exclusion criteria, so as to mitigate any possible selection bias. These studies show the vulnerability of the workers who are exposed to infection without the appropriate immunization 5,21,22,26,29.

Another limitation of some studies is the small number of subjects included (Table 1). This limits the representativeness of the study population. Considering prevalence for exposed and non-exposed subjects, seven studies 5,19,21,22,24,25,29 did not have a sufficient sample size to ensure statistical significance, according to Kelsey et al. 30 .

Five studies 5,19,21,22,25 included workers in activities not associated with waste collection as the control group. Other studies $26,27,28,29$ included household waste collectors as the control group. Finally, two studies 23,24 had no control groups at all.

Some studies do not describe any method to control for confounding factors, such as sexual 
Table 1

Articles selected for inclusion in this review (in order of year of publication).

\begin{tabular}{|c|c|c|c|c|c|c|}
\hline Reference & $\begin{array}{l}\text { Date of } \\
\text { study }\end{array}$ & Country & $\begin{array}{l}\text { Sample } \\
\text { size }\end{array}$ & Study groups & $\begin{array}{l}\text { Outcome } \\
\text { measure * }\end{array}$ & Findings \\
\hline Anagaw, et al. 27 & $\begin{array}{l}\text { April- June } \\
2011\end{array}$ & Ethiopia & 200 & $\begin{array}{l}100 \text { collectors of health } \\
\text { care waste (hospital) \& } 100 \\
\text { cleaning staff (who collect } \\
\text { ordinary waste) }\end{array}$ & $\begin{array}{l}\text { HBV (HBsAg), } \\
\text { HCV (Anti-HCV) }\end{array}$ & $\begin{array}{l}\text { HBV (OR: } 6.3 ; p=0.04) ; \mathrm{HCV}(\mathrm{OR}: 7.5 ; p= \\
0.02) \text {. Prevalence of HBV \& HCV significantly } \\
\text { higher in workers collecting health care waste }\end{array}$ \\
\hline Rachiotis et al. 21 & $2007-2008$ & Greece & 210 & $\begin{array}{l}102 \text { collectors of urban } \\
\text { solid waste and } 108 \\
\text { gardeners }\end{array}$ & $\begin{array}{l}\text { HBV (HBsAg, } \\
\text { Anti-HBc and } \\
\text { Anti-HBs) }\end{array}$ & $\begin{array}{l}\text { HBV (OR: } 4.05 ; 95 \% \mathrm{Cl}: 1.23-13.33)- \\
\text { progressive increase risk for infection with age. } \\
\text { Accidents with sharps (RR: } 2.64 \\
95 \% \mathrm{Cl}: 1.01-6.96)\end{array}$ \\
\hline Shiferaw et al. 26 & $\begin{array}{l}\text { May- July } \\
2010\end{array}$ & Ethiopia & 252 & $\begin{array}{l}126 \text { collectors of health care } \\
\text { waste (hospital) \& } 126 \text { who } \\
\text { collect normal non-clinical } \\
\text { waste in a hospital }\end{array}$ & $\begin{array}{l}\text { HBV (HbsAg and } \\
\text { Anti-HBcAg) }\end{array}$ & $\begin{array}{l}\text { HBsAg (OR: } 8 ; 95 \% \mathrm{Cl}: 1.02-63.02) \text {; Anti-HBcAg } \\
\text { (OR: } 1.5 ; 95 \% \mathrm{Cl}: 1.1-2.1) \text {. High prevalence of } \\
\text { HBV in workers collecting health care waste } \\
\text { compared with those who do not }\end{array}$ \\
\hline Graudenz 5 & $\begin{array}{l}\text { September } \\
\text { 2007/ } \\
\text { February } \\
2008\end{array}$ & Brazil & 217 & $\begin{array}{l}64 \text { (landfill), } 41 \text { (urban } \\
\text { solid waste collection), } 35 \\
\text { (sweepers), } 45 \text { (drivers) } \\
\text { \& } 32 \text { controls (railway } \\
\text { maintenance) }\end{array}$ & HBV (Anti-HBc) & $\begin{array}{c}\text { No difference in prevalence of hepatitis } \mathrm{B} \\
\text { between study groups (percentage positive } \\
\text { varied between groups from } 6.3 \text { to } 20 \\
\text { with } p=0.439 \text { ) }\end{array}$ \\
\hline Franka et al. 28 & $\begin{array}{l}\text { January- } \\
\text { December } \\
2004\end{array}$ & Libya & 600 & $\begin{array}{c}300 \text { collectors of health } \\
\text { care waste (medical center) } \\
\text { and } 300 \text { who collect only } \\
\text { ordinary waste (urban solid } \\
\text { waste) }\end{array}$ & $\begin{array}{l}\text { HIV, HBV (HBsAg), } \\
\text { HCV (Anti-HCV) }\end{array}$ & $\begin{array}{l}\text { HBV (OR: 7.14; } p<0.04) \text {; HCV (OR: not } \\
\text { given; } p<0.005) \text {. HIV not detected. Higher } \\
\text { prevalence of HBV \& HCV in health care waste } \\
\text { group than in urban solid waste group }\end{array}$ \\
\hline $\begin{array}{l}\text { Luksamijarulkul et } \\
\text { al. } 25\end{array}$ & Not stated & Thailand & 354 & $\begin{array}{l}169 \text { collectors of urban } \\
\text { solid waste \& } 185 \text { public } \\
\text { cleansing workers (not in } \\
\text { direct contact with waste) }\end{array}$ & $\begin{array}{l}\text { HAV, HBV } \\
\text { (HBsAg, Anti-HBs } \\
\text { and Anti-HBc) }\end{array}$ & $\begin{array}{l}\text { 49.4\% seropositive for HBV, } 5.9 \% \text { for } \mathrm{HBsAg} \text {, } \\
37.3 \% \text { for anti-HBs, } 6.2 \% \text { only for anti-HBc, \& } \\
\text { 85\% with anti-HAV antibodies ( } p=0.0058 \text { mos } \\
\text { exposed collectors). For HAV no significant } \\
\text { difference was found }\end{array}$ \\
\hline Squeri et al. 23 & $\begin{array}{l}\text { March- May } \\
2005\end{array}$ & Italy & 327 & $\begin{array}{l}\text { All were workers who } \\
\text { collected urban solid waste }\end{array}$ & $\begin{array}{l}\text { HBV }(\mathrm{HBsAg} \text { and } \\
\text { Anti-HBC), HCV } \\
\text { (Anti-HCV) }\end{array}$ & $\begin{array}{c}183(55.96 \%) \text { protected from HBV by the } \\
\text { presence of HBsAb ( } 98 \text { by immunization and } \\
85 \text { by previous contact). } 120 \text { ( } 36.7 \%) \text { at risk of } \\
\text { infection. } 24(7.34 \%) \text { infected by HBV and } 5 \\
\text { (1.52\%) had contact with HBV and HCV }\end{array}$ \\
\hline Mariolis et al. 24 & Not stated & Greece & 69 & $\begin{array}{l}\text { All were workers who } \\
\text { collected urban solid waste }\end{array}$ & $\begin{array}{c}\text { HAV, HBV (HBsAg, } \\
\text { Anti-HBs and Anti- } \\
\text { HBC), HCV (Anti- } \\
\text { HCV) }\end{array}$ & $\begin{array}{l}37(53.6 \%) \text { were HAV positive; } 15(21.7 \%) \text { had } \\
\text { been exposed to HBV. Of the whole study } \\
\text { group, } 7 \text { (10.1\%) had been immunised against } \\
\text { HBV. } 4.3 \% \text { were HBV chronically infected. One } \\
\text { was found to be HCV positive }\end{array}$ \\
\hline Dounias et al. 22 & $\begin{array}{l}\text { September } \\
\text { 1999/ } \\
\text { December } \\
2001\end{array}$ & Greece & 159 & $\begin{array}{l}71 \text { collectors of urban solid } \\
\text { waste } \& 88 \text { office workers } \\
\text { (not in direct contact with } \\
\text { waste) }\end{array}$ & $\begin{array}{l}\text { HBV (HBsAg, Anti- } \\
\text { HBs and Anti-HBc) }\end{array}$ & $\begin{array}{l}\text { Prevalence of HBsAg was higher in exposed } \\
\text { (11.3\%) than in non-exposed (4.5\%), but } \\
\text { difference was not significant. Prevalence of } \\
\text { anti-HBc was } 24 \% \text { among exposed and } 8 \% \text { in } \\
\text { non-exposed, also not significant }\end{array}$ \\
\hline Ferreira et al. 29 & $\begin{array}{l}\text { May- July } \\
1996\end{array}$ & Brazil & 186 & $\begin{array}{l}31 \text { collectors de health } \\
\text { care waste (hospitals) \& } \\
155 \text { collectors of domestic } \\
\text { urban solid waste }\end{array}$ & HBV (Anti-HBc) & $\begin{array}{l}\text { HBV (OR: } 0.9 ; 95 \% \mathrm{Cl}: 0.24-3.05 ;) \text { No } \\
\text { significant difference in risk found between the } \\
\text { groups of workers studied }\end{array}$ \\
\hline Corrao et al. 19 & Not stated & Italy & 93 & $\begin{array}{l}45 \text { sweepers, } 21 \text { waste } \\
\text { collectors, } 19 \text { machine } \\
\text { operators, } 5 \text { sewer workers } \\
\text { and } 3 \text { office workers }\end{array}$ & $\begin{array}{c}\mathrm{HAV}, \mathrm{HBV}(\mathrm{HBsAg} \\
\text { Anti-HBs and Anti- } \\
\mathrm{Hbc} \text { ) }\end{array}$ & $\begin{array}{c}\text { Positive for HBV in each group were: } 9(20.0 \% \\
\text { sweepers, } 6(28.6 \%) \text { waste collectors, } 1(5.3 \%) \\
\text { machine operator, } 2 \text { (40.0\%) sewer workers } \\
\text { and } 0(0.0 \%) \text { among the office workers }\end{array}$ \\
\hline
\end{tabular}

* Sensitivities of serology tests for Hepatitis B: Anti-HBc - detects acute, chronic, cure stages; HbsAg - detects incubation, acute, chronic stages;

Anti-HBs - vaccinated. 


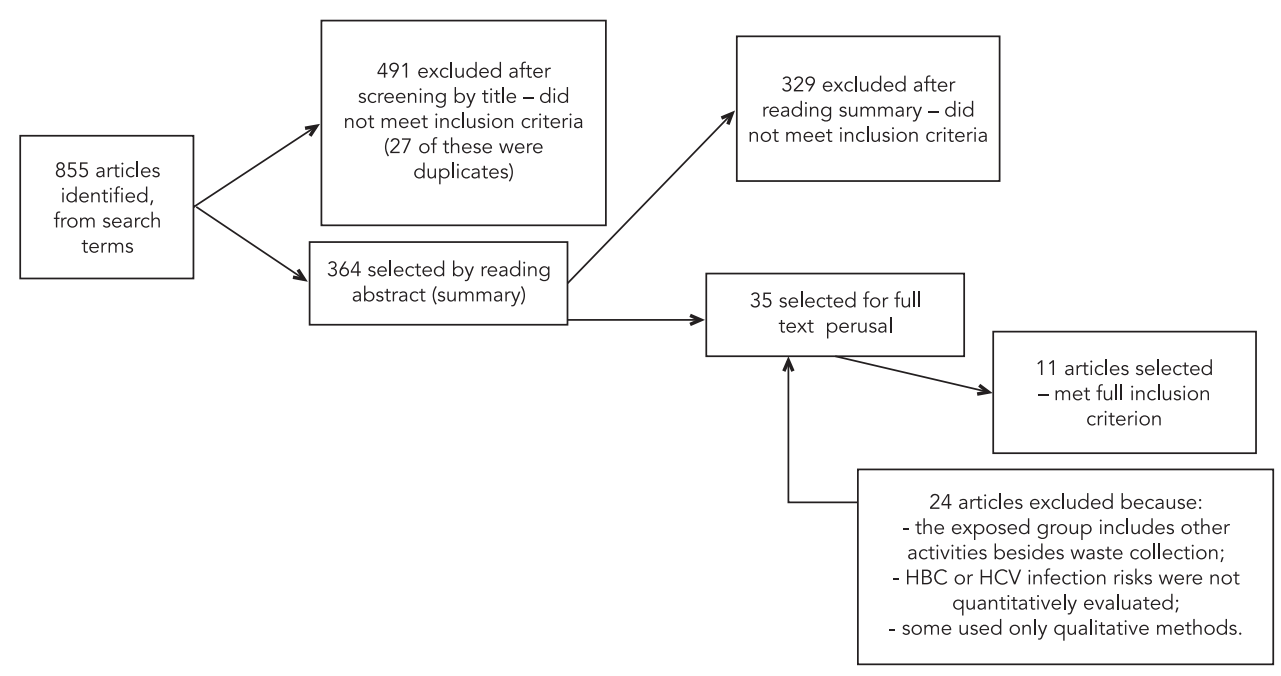

behavior, injecting drug use or accidents involving sharps 19,23,24,5,28.

Two papers 26,27 show that accidents with sharps and the use of injectable drugs do not affect the statistical significance of the association between exposure and infection with HBV.

Finally, other studies 21,22 examine several potential confounders, such as age, level of schooling and exposure to waste, and find a significant association.

\section{Conclusion}

The small number of papers found in this review suggests that the theme would benefit from research in greater depth. While most studies indicate a possible association between exposure to waste and infection by HBV or HCV, further research is needed to clarify this.

The papers in this review suggest that the handling of health care waste involves a higher risk of infection with $\mathrm{HBV}$ and $\mathrm{HCV}$, compared with urban solid waste handlers. The studies providing the main evidence for that conclusion were based in hospitals, and no information is available about the separation of different categories of waste.

It must be emphasized that vaccination against hepatitis B is mandatory to protect workers who are exposed to waste, urban solid waste or health care waste, and it must be a sine qua non part of the admission process for these workers. An immunization evidentiary test is also recommended to ensure the success of vaccination. 


\section{Resumen}

El contacto humano con los residuos implica riesgos biológicos, químicos y físicos para la salud de los trabajadores que participan en su recogida, transporte y almacenamiento. El riesgo potencial para la salud humana, como resultado del contacto con los desechos médicos o del hogar, sigue generando mucha controversia. Por lo tanto, el propósito de este estudio fue identificar el contexto de las discusiones científicas sobre el riesgo/infección por el virus de la hepatitis B y C en los trabajadores de recolección de residuos de servicios de salud o del hogar. Fueron recogidos artículos publicados hasta 2013 en bancos de datos nacionales e internacionales; se seleccionaron 11 artículos a través de una revisión de la literatura, seis de los cuales concluyen que hay un mayor riesgo de infección entre los trabajadores que recogen la basura doméstica, en comparación con los no expuestos a los residuos, tres estudios sugieren que existe un mayor riesgo entre los profesionales que recogen los residuos médicos, en comparación con los que la recogida de residuos ordinarios, y otras dos concluyen que no había diferencias entre expuestos y no expuestos.

Residuos Sólidos; Hepatitis B; Hepatitis C; Salud Urbana

\section{Contributors}

M. P. G. Mol and L. Heller conceived the study, analyzed and interpreted the results, and were responsible for precision and integrity in all aspects of the work. D. B. Greco and S. Cairncross were responsible for critical review of the manuscript for its intellectual content and approval of the published version.

\section{Acknowledgments}

We acknowledge the research incentives provide by the Fundação Ezequiel Dias (Funed) and the financial support of the Fundação de Amparo à Pesquisa do Estado de Minas Gerais (FAPEMIG).

\section{References}

1. Catapreta CAA, Heller L. Associação entre coleta de resíduos sólidos domiciliares e saúde, Belo Horizonte (MG), Brasil. Rev Panam Salud Pública 1999; 5:88-96.

2. Porta D, Milani S, Lazzarino AI, Perucci CA, Forastiere F. Systematic review of epidemiological studies on health effects associated with management of solid waste. Environ Health 2009; 8:60.

3. Athanasiou M, Makrynos G, Dounias G. Respiratory health of municipal solid waste workers. Occup Med 2010; 60:618-23.
4. Marinho TA, Lopes CLR, Teles SA, Reis NRS, Carneiro MAS, de Andrade AA, et al. Prevalence of hepatitis $C$ virus infection among recyclable waste collectors in Central-West Brazil. Mem Inst Oswaldo Cruz 2013; 108:519-22.

5. Graudenz GS. Indicadores infecciosos e inflamatórios entre trabalhadores da limpeza urbana em São Paulo. Rev Bras Saúde Ocup 2009; 34:106-14.

6. Rushton L. Health hazards and waste management. Br Med Bull 2003; 68:183-97. 
7. Oliveira MG. Características organizacionais e acidentes ocupacionais em empresas de limpeza urbana em Salvador-BA. Salvador: Universidade Federal da Bahia; 2007.

8. Domingo JL, Nadal M. Domestic waste composting facilities: a review of human health risks. Environ Int 2009; 35:382-9.

9. Takayanagui AMM. Gerenciamento de resíduos de serviços de saúde. In: Philippi Jr. A, organizador. Saneamento, saúde e ambiente: fundamentos para um desenvolvimento sustentável. Barueri: Manole; 2005. p. 323-74.

10. Tramontini ACB. Resíduos sólidos de serviço de saúde: diagnóstico e diretrizes para gestão hospitalar. Passo Fundo: Universidade de Passo Fundo; 2009.

11. World Health Organization. Wastes from healthcare activities. http://www.who.int/mediacentre/ factsheets/fs253/en/ (accessed on 11/Sep/2013).

12. Tooher R, Griffin T, Shute E, Maddern G. Vaccinations for waste-handling workers. A review of the literature. Waste Manage Res 2005; 23:79-86.

13. Gershon RRM, Mitchell C, Sherman MF, Vlahov D, Lears MK, Felknor S, et al. Hepatitis B vaccination in correctional health care workers. Am J Infect Control 2005; 33:510-8.

14. Johnson KR, Braden CR, Cairns KL, Field KW, Colombel AC, Yang Z, et al. Transmission of Mycobacterium tuberculosis from medical waste. JAMA 2000; 284:1683-8.

15. Cussiol NAM. Disposição final de resíduos potencialmente infectantes de serviços de saúde em célula especial e por co-disposição com resíduos sólidos urbanos. Belo Horizonte: Universidade Federal de Minas Gerais; 2005.

16. Ferreira JA. Lixo hospitalar e domiciliar: semelhanças e diferenças estudo de caso no município do Rio de Janeiro. Rio de Janeiro: Fundação Oswaldo Cruz; 1997.

17. Mühlich M, Scherrer M, Daschner FD. Comparison of infectious waste management in European hospitals. J Hosp Infect 2003; 55:260-8.

18. Borg MA. Clinical waste disposal: getting the facts right. J Hosp Infect 2007; 65:178-9.

19. Corrao G, Zotti C, Sciacovelli A, Bosia S, Piccioni P. Infezioni da virus delle epatiti A e B negli addetti alla raccolta rifiuti di Asti. G Ital Med Lav 1985; 7:145-7.

20. Corrao CRN, Del Cimmuto A, Marzuillo C, Paparo E, La Torre G. Association between waste management and HBV among solid municipal waste workers: a systematic review and meta-analysis of observational studies. ScientificWorldJournal 2013; 2013:692083.
21. Rachiotis G, Papagiannis D, Markas D, Thanasias E, Dounias G, Hadjichristodoulou C. Hepatitis B virus infection and waste collection: prevalence, risk factors, and infection pathway. Am J Ind Med 2012; 55:650-5.

22. Dounias G, Kypraiou E, Rachiotis G, Tsovili E, Kostopoulos S. Prevalence of hepatitis B virus markers in municipal solid waste workers in Keratsini (Greece). Occup Med 2005; 55:60-3.

23. Squeri R, Fauci VL, Sindoni L, Cannavo G, Spagnolo EV. Study on hepatitis B and C serologic status among municipal solid waste workers in Messina (Italy). J Prev Med Hyg 2006; 47:110-3.

24. Mariolis A, Mihas C, Magaziotou I, Alevizos A, Gizlis V, Papathanasiou M, et al. Seroepidemiological study of viral hepatitis among workers of the Cleaning Department of the Municipality of Vyronas: preliminary results of a single centre study. Public Health 2006; 120:1088-9.

25. Luksamijarulkul P, Sujirarat D, Charupoonphol P. Risk behaviors, occupational risk and seroprevalence of hepatitis B and A infections among public cleansing workers of Bangkok Metropolis. Hepat Mon 2008; 8:35-40.

26. Shiferaw Y, Abebe T, Mihret A. Hepatitis B virus infection among medical waste handlers in Addis Ababa, Ethiopia. BMC Res Notes 2011; 4:479.

27. Anagaw B, Shiferaw Y, Belyhun Y, Erku W, Biadgelegn F, Moges B, et al. Seroprevalence of hepatitis $B$ and $C$ viruses among medical waste handlers at Gondar town Health institutions, Northwest Ethiopia. BMC Res Notes 2012; 5:55.

28. Franka E, El-Zoka AH, Hussein AH, Elbakosh MM, Arafa AK, Ghenghesh KS. Hepatitis B virus and hepatitis $C$ virus in medical waste handlers in Tripoli, Libya. J Hosp Infect 2009; 72:258-61.

29. Ferreira JA, Tambellini AT, Silva CLP, Guimaraens MAAM. Hepatitis B morbidity in municipal and hospital waste collection workers in the City of Rio de Janeiro. Infect Control Hosp Epidemiol 1999; 20:591-2.

30. Kelsey JL, Whittemore AS, Evans AS, Thompson WD. Methods in observational epidemiology. $2^{\text {nd }}$ Ed. New York: Oxford University Press; 1996.

Submitted on 28/May/2014

Final version resubmitted on $08 / \mathrm{Jul} / 2015$

Approved on 09/Sep/2015 